\title{
Management and Final Disposal of Mango Waste in the State of Guerrero, Mexico: A Brief Review
}

\author{
M. A. Lorenzo-Santiago ${ }^{1}$, A. L. Juárez-López ${ }^{1}$, J. L. Rosas-Acevedo ${ }^{1}$, J. R. Rendón-Villalobos ${ }^{2}$, \\ J. Toribio-Jiménez ${ }^{1}$ \& E. García-Hernández ${ }^{3}$ \\ ${ }^{1}$ Centro de Ciencias de Desarrollo Regional, Universidad Autónoma de Guerrero, Acapulco, Guerrero, México \\ ${ }^{2}$ Centro de Desarrollo de Productos Bióticos, Instituto Politécnico Nacional, Yautepec, Morelos, México \\ ${ }^{3}$ Instituto Tecnológico de Zacatepec, Zacatepec, Morelos, México \\ Correspondence: A. L. Juárez-López, Centro de Ciencias de Desarrollo Regional, Universidad Autónoma de \\ Guerrero, Privada de Laurel No. 13 Col. El Roble. C.P. 39640, Acapulco, Gro., México. Tel: 01-(744)-469-0430. \\ E-mail: analaura43@hotmail.com
}

Received: August 23, 2018

doi:10.5539/jas.v10n12p34

\author{
Accepted: September 27, 2018 \\ Online Published: November 15, 2018 \\ URL: https://doi.org/10.5539/jas.v10n12p34
}

\begin{abstract}
One fruit trees crops with largest amount in Mexico is the mango (Mangifera indica L.). In 2017, Guerrero was the state with the highest production in the country. However, the waste generated after harvesting represents an environmental problem caused by high production and low opportunity in the national and international markets. Nowadays, there is no environmental policy to regulate this final waste disposal. Regularly, post-harvest waste has no value and most of the time, its disposal is inadequate. The lack of training and management knowledge, separation and use, has generated an imbalance in the environment, caused by inadequate elimination practices and excessive use of pest prevention activities, known as cultural control. The main objective of this review was to know about mango production in Guerrero State, its final disposal after harvest and the environmental impact generated by cultural control use.
\end{abstract}

Keywords: agricultural waste, cultural control, final disposal, mango production

\section{Introduction}

Pollution in the world is attributed to different actions. However, the base is found in the excessive use of natural resources, the lack of environmental education and anthropogenic activities. Nowadays, the final disposal inadequate of waste has generated environmental and health problems.

Agriculture in Mexico is an important productive sector. Its participation in the economic, social and environmental branch determines its greatest impact on the development of the country. For that reason, one of the long-term goals is the conservation and use of natural resources and environmental sustainability. Agricultural waste or byproducts represent an environmental problem, due to the lack of policies for its adequate management and final disposal (Quispe Limaylla, 2015).

The agricultural farming activities generate organic waste whose indiscriminate disposal can be prejudicial to the environment (De Sousa Oliveira et al., 2018). In Mexico, agricultural waste represents an environmental problem, because there are no adequate management practices, and most of the time, they are thrown into uncontrolled sites. The waste is converted into large volumes and only part is reused in the production of animal food, in the production of handicrafts and composting (Sumaya-Martínez et al., 2012). It is necessary to increase the exploitation of agricultural waste and to promote multidisciplinary work to generate research that helps to visualize opportunities and develop new products and innovate from them.

The mango (Mangifera indica L.) is one of the fruit crops with the highest production in Mexico (SAGARPA-SIAP, 2018). For several years, the State of Guerrero has occupied the first places in production in the country. The fruit is an important source of income for the coastal areas of the state. However, high production, low opening in the national and international markets and the presence of pests, have generated an increase in the generation of post-harvest waste, which represents a serious environmental and economic problem. 


\section{Mango Production}

Mango (Mangifera indica L.) fruit belongs to the family of Anacardiaceae in the order of Sapindales and it is grown in many parts of the world (Jahurul et al., 2015). Mango farming is limited to tropical and subtropical climatic zones, its optimum growth temperature goes from 24 to $27^{\circ} \mathrm{C}$ approximately and the soil water content is essential to the early development of mango fruit. Water supply is most critical during the first 42 days, of the fruit's development; drought can induce late-stage fruit dropping and reduce fruit mass via decreased size (Wei et al., 2017).

Although this fruit comes from India, it is now grown in almost all tropical and subtropical agroecosystems of the world. Around 95 countries have commercial plantations that produce 30 million tons, out of which the majority is consumed internally and only $3 \%$ is exported. Asian countries harvest $77 \%$ of world's production, Latin America contributes 13\% and other producers contribute the remaining 10\% (FAOSTAT, 2016).

The countries highlighted by their high production are India, China, Thailand, Indonesia, Mexico, the Philippines and Pakistan. However, mango production is growing outside traditional regions, such as Central America, South America, Australia, Southeast Asia, Egypt, Israel, among others (Tharanathan et al., 2006). The mature fruit is considered an excellent vitamins' C, B1, B2 and provitamin A source (Mukherjee \& Litz, 2009). In addition to this, the mango pulp is rich in fermentable sugars and dietary fiber (Giraldo et al., 2007; Ajila \& Rao, 2013).

\subsection{Mango Production in Mexico}

Fruit mango trees represent in Mexico a very important economic opportunity due to its high production per planted hectare. In 2017, the mango ranked fourth in fruit trees most planted and the fifth place in production, (Table 1).

Table 1. Fruit crops with higher production per planted hectare in Mexico

\begin{tabular}{lllll}
\hline Fruit crop & Area in hectares & Production (tons) & hectares damaged (ha) & Yield per hectare (ton/ha) \\
\hline Orange & 340586 & 4670259 & 24 & 14.403 \\
Banana & 77229 & 2203069 & 1155 & 28.527 \\
Lemon & 198310 & 2520797 & 31 & 14.686 \\
Avocado & 220334 & 1997629 & 43 & 10.276 \\
Mango & 201423 & 1958132 & 1207 & 10.384 \\
Pineapple & 388448 & 954002 & - & 47.227 \\
Tuna & 47984 & 469844 & 377 & 10.356 \\
Grapefruit & 20127 & 451814 & 9 & 24.152 \\
Grape & 33702 & 418511 & 75 & 13.907 \\
\hline
\end{tabular}

Source: SAGARPA-SIAP, 2018.

In Mexico, mangoes grow at an average altitude of 450 meters above sea level, they need an annual rainfall of 1200 to $1500 \mathrm{~mm}$, temperatures between 24 and $27^{\circ} \mathrm{C}$, deep textured soils, drained and with $\mathrm{pH} 6.0$ to 8.0. For this reason, the largest mango production volumes are located in the coastal states (Figure 1), one in every 25 mangoes consumed in the world is Mexican (SAGARPA-SIAP, 2018).

The varieties of greatest export are Tommy Atkins (33\%), Ataulfo (25\%), Kent (21\%) and the rest are perishable varieties (Infante et al., 2011). It is estimated 2.40\% annual growth in Mexico from 2016 to 2030 (SAGARPA-SIAP, 2017). Manila variety occupies the largest planted amount in Mexico. However, a small volume is exported. Its consumption is local because it has a very short shelf life. 


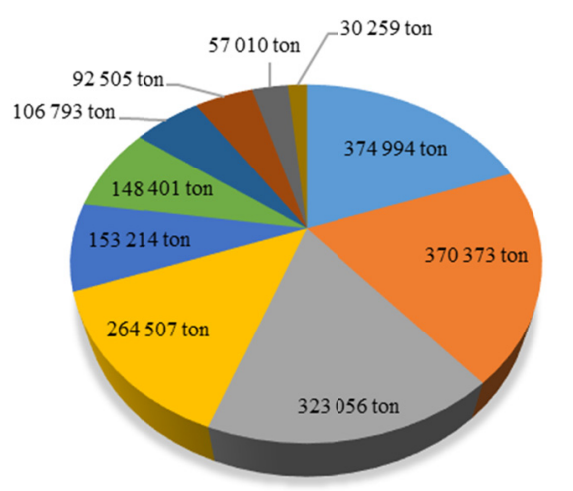

$$
\begin{aligned}
& \square 1 \text { Guerrero } \\
& \square 2 \text { Sinaloa } \\
& \square 3 \text { Nayarit } \\
& ₫ 4 \text { Chiapas } \\
& \square 5 \text { Michoacán } \\
& \square 6 \text { Oaxaca } \\
& \square 7 \text { Jalisco } \\
& \square 8 \text { Veracruz } \\
& \square 9 \text { Colima } \\
& \square 10 \text { Campeche }
\end{aligned}
$$

Figure 1. States producers of mango in 2017

Source: SAGARPA-SIAP, 2018.

\subsection{Mango Production in Guerrero State}

Mango production in Guerrero State is in the economic regions known as Costa Grande, Costa Chica and Tierra Caliente, (Figure 2). The harvest begins in February and continues until June, with another season from August to September. The region with the highest production and area planted in Guerrero State is Costa Grande with 14,976 hectares, covered with $46.6 \%$ area with Ataulfo variety, followed by Manila, Haden, Tommy Atkins and Criollo with $39.0,8.3,5.2$ and $0.6 \%$, respectively.

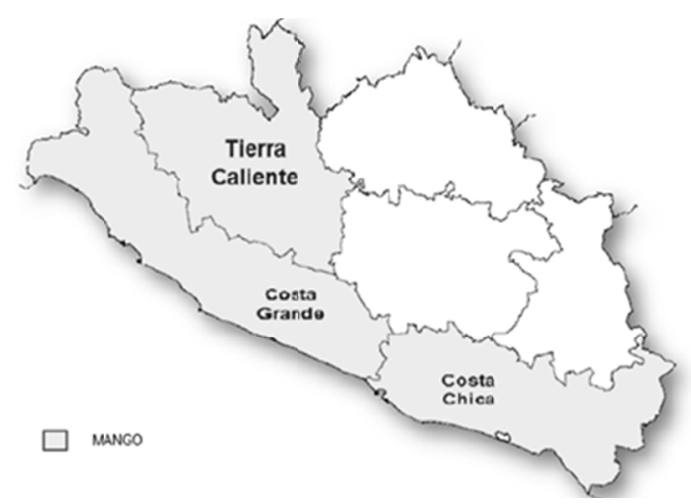

Figure 2. Main mango producing regions in Guerrero State

Source: SAGARPA, 2011.

Técpan de Galeana, La Union, Atoyac de Álvarez, Zihuatanejo and Cuajinicuilapa municipalities are the main mango producers in Guerrero State (SAGARPA-SIAP, 2018). The outstanding national production contribution implies that mango cultivation has a socioeconomic importance for Guerrero State; this activity employs 7000 producers, suppliers and rural day laborers (RDS, 2003).

In the last five years, Guerrero State has been the main mango producer in the country. In 2017, mango production in Mexico was 1958132 tons, of which Guerrero contributed 374994 tons, 12.62\% more than in 2012, on average, its production increased $2.01 \%$ annually (Figure 3a). Thousands of tons of mango are not exploited, because the fruit is small, have malformations or by the presence of pests. In 2017, approximately 35400 tons of mango were not commercialized, generating accumulation in the orchards and problems for their elimination (SAGARPA-SIAP, 2018) (Figure 3b). 

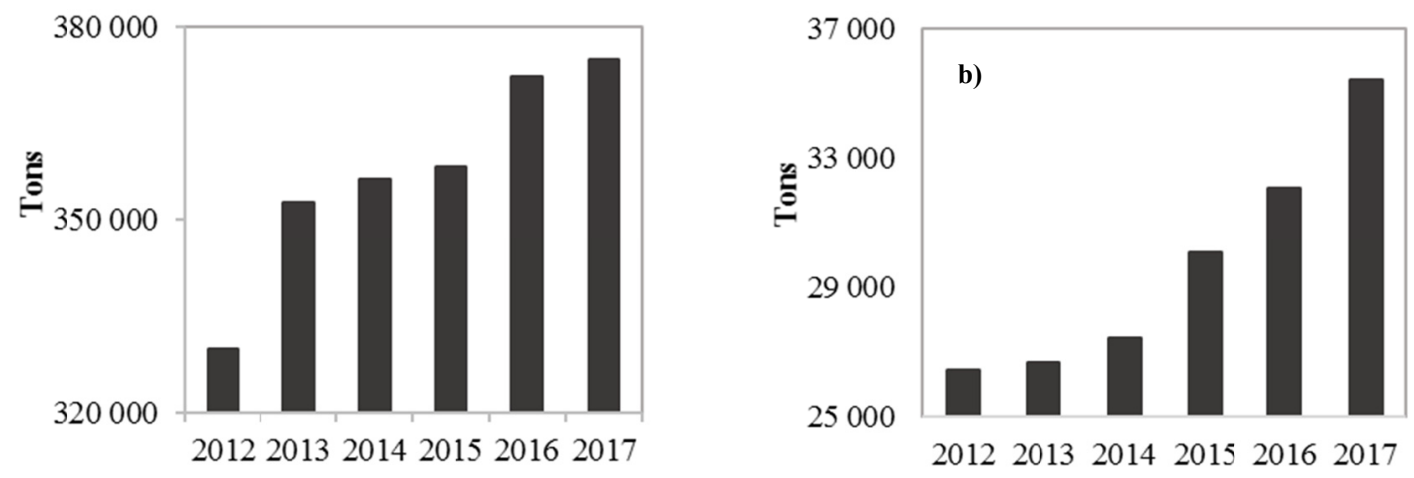

Figure 3. a) Mango production in Guerrero, from 2012 to 2017 and b) Tons of mango fruit waste not commercialized

Source: SAGARPA-SIAP, 2018.

In Guerrero, there is no characterization of pre- and post-harvest pruning waste. However, its large volumes generate the greatest impact on the ecosystem.

\section{Final Disposal of Agricultural Waste in Guerrero State}

The orchards of mango generate a large amount of waste. However, the greatest amount is generated during the pruning of the trees. The first stage is called training pruning, this action is carried out during the first three years of development of the plant; this provides an adequate structure and avoids the tearing of the branches by the weight of the fruits. The second stage is known as production pruning, its purpose is to regularize and improve production efficiency, through maintenance, and finally pruning of sanitation, this activity generates a large amount of post-harvest waste. The sanitary pruning consists on eliminating the dry and diseased branches, as well as the remains of the previous harvest (peduncles and sick fruits adhered), which constitute the most important source of pests of the next harvest (Avilán et al., 2003).

The elimination of leaves and removal of cross branches in the centre of the cup allows adequate aeration and solar lighting. This avoids microclimates (specific humidity and temperature conditions) that favor the development of diseases and pests.

Acapulco, Chilapa, Ometepec, Buenavista de Cuellar and Zapotitlán Tablas, towns in the State of Guerrero, have worked in the construction of landfills in compliance with the Official Mexican Standard NOM-083-SEMARNAT-2003. However, in most of the communities the wastes are not collected properly, the final disposal is made in open dumps, ravines or riverbeds without any type of control, contaminating air, water and soil (Juárez-López et al., 2015). The final disposal of organic waste in Guerrero State is carried out in places that do not comply with the guidelines of a landfill.

In Guerrero State, there is no agricultural waste management program, most of the generated wastes are deposited in uncontrolled sites, incinerated or sprayed with pesticides (Noriega-Cantú et al., 2014), an activity known as cultural control.

\section{Mango value chain in Guerrero State}

In Guerrero, the value network of mango has a very low competitive level. This has an economic activity integrated by a set of stages that go from the fruit production to its consumption. However, there are some critical points that generate negative economic repercussions for the fruit growers, the stages that are most affected are: production, and marketing (Santos-Villalobos et al., 2011). The main limitations are in the postharvest infrastructure, the poor quality of packaging, the lack facilities for cold storage (only production for export receives treatment) and the null quality standards (Sumaya-Martínez et al., 2012). The producers of mango, which are the key players in the network, have not qualified in business or as suppliers do they have not designed and implemented strategies in for their business, neither are there any certifications of good practice in production and post-harvest processes.

Another concurrent problem is the raw material exploitation for industrialization. Although its fresh production is privileged, at the same time, there are losses caused by the intermediaries, who are responsible for buying orchards that meet certain parameters for fresh sale and export. After the harvest, they generate a large amount of raw material waste, but they have not an adequate final disposal (Rivas Tovar et al., 2005). 


\section{Economic Importance Pests in Guerrero State}

The most important problems in Guerrero's fruit crops are caused by pests. They affect the production and the economic costs to the producer. Some of the most common pests in the orchards are the fruit fly, scale, thrips and mites (Duran-Trujillo et al., 2017). The fruit fly is considered one of the 10 most economically important agricultural pests in the world. The genus Anastrepha (Diptera: Teptitidae) is endemic to the new world and it is restricted to tropical and subtropical environments. It is distributed from south of the United States to north of Argentina; including most of the islands of the Caribbean. To date, they are 195 species described out of which, the most economically important are: Anastrepha ludens L., Anastrepha obliqua (Macquart), Anastrepha serpentina (Wiedemann) and Anastrepha striata (Schiner).They affect more than 30 species of fruit trees that are grown for commercial purposes and 60 that grow on a smaller scale (Munro-Olmos et al., 2008).

In Guerrero State, several programs and strategies have been applied to eradicate the fruit fly (Anastrepha spp), the most important regional program in phytosanitary control was "Moscamed" being (SENASICA, 2010). However, the program did not have any appropriate functions, because the effect of physiological maturity of fruit is was not considered, which can be determinant for the success of infestation and the development of insect larvae inside the fruit.

Fruit fly infestation has led to large losses in the yield and quality of fresh fruits and quarantine restrictions has made markets sensitive throughout the world. The lack of knowledge and limited awareness of stakeholders throughout the mango value chain is what generates an economic impact, lack of management strategies and knowledge of species (Billah et al., 2015).

\section{Cultural Control Application}

At present, it is not possible to exploit the fruit of mango with high yields and competitive prices without the use of protective measures, among which, chemical pesticides continue to have a considerable participation (Noriega-Cantú et al., 2014). The fruit orchards are very susceptible to pests, since the fruits are rich in nutrients that help the growth of bacteria, fungi, flies and native fauna. Producers usually use chemicals (fumigations), biologicals control (fungi or modified insects) and cultural controls to mitigate or prevent them.

The cultural control consists of eliminating the fruit or the tree that presents the anomaly, to reduce the infestation percentage caused by the pests. If the farmer correctly applies the control, he can reduce $50 \%$ the flies presence (Noriega-Cantú et al., 2014). However, the excessive use of pesticides is generating microorganisms resistance, soil deterioration and water pollution, modifying the life quality of people's quality of life and generating impact in all trophic chains.

To apply cultural control, one must know the host, the pathogen and the climate; that is, the mango growth phases, epidemiological studies of the pathogen and climatological information, as well as the susceptibility of the cultivate, which indicates that the application of contact products with preventive character makes a lot of sense to diminish the pathogens.

In the State of Guerrero, cultural control is mostly used due to its low cost. These activities are applied in the fruits' harvest when farmers detect the presence of pests accumulated in the fruits, they spray with insecticide or incinerate all trees (Rodríguez et al., 2002; Acosta et al., 2003; Mukherjee \& Litz, 2009). These practices alter habitats to create less suitable environments for pests but directly affect all ecosystems (Jenkins and Isaacs, 2014).

\section{Alternatives for the Use of Mango Waste}

One of the main factors that does not allow the economic sector's competitiveness of the mango system and its wastes, is the lack of innovation products with added value to diversify the industrialized mango market and to value the waste generated in each one the stages of its productive chain.

Nowadays, mango wastes have little impact in the industry; only a few of the producers take advantage of waste to obtain new products. However, there is a sector committed to innovation products from waste. Currently, mango pulp in green physiological state and cotyledons, are used to obtain starch; a biopolymer very useful in obtaining biodegradable plastics, in the cosmetic and food industry (Martínez et al., 2010; Lorenzo-Santiago et al., 2017). The fibrous endocarp as cellulose source, is used as a reinforcement for biodegradable films and, in order to obtain paper (Cordeiro et al., 2014; Lorenzo-Santiago et al., 2016); the peel contains pectin and it is used as natural thickeners in food industry (Serna-Cock \& Torres-León, 2015). In addition, mango byproducts are used as raw material in the production of reducing sugars, microbial biomass, organic acids production and to obtain alcohols (Giraldo et al., 2007). 
Other alternatives for the use of agricultural residues, is the obtaining of bioplastics or biomaterials composed of natural polymers and biomass (Rubio-Anaya \& Guerrero-Beltrán, 2012). These could offer some solutions to solve environmental problems, among them contamination by plastic waste that threatens all ecosystems, among them, being the oceans the most affected (O'Brine \& Thompson, 2010; Webb et al., 2012).

\section{Conclusions}

The use of agricultural waste as a source to obtain biodegradable materials would provide benefits from waste and reduce the impact generated by the intentional burning and excessive use of pesticides as cultural control. For this reason, it is necessary to determine the number of tons of waste that is generated before and after the harvest, as well as the production of waste generated by orchards that are not in the SAGARPA registry and thus, to be able to influence the normative to help reduce the impact generated by the inadequate disposal of these wastes.

\section{References}

Acosta, M. R., Noriega, D. H., Nieto, D. A., \& Téliz, D. O. (2003). Efecto del manejo integrado del mango (Mangifera indica L.) en la incidencia de enfermedades y en la calidad de frutos. Revista Mexicana de Fitopatología, 21(01), 46-55.

Avilán, L., G. Martínez, C., Marín R., Rodríguez, M., Ruiz, J., \&Escalante, H. (2003). La poda cuadrada y piramidal truncada con y sin aserrado en la producción del mango. Agronomía Tropical, 53(3), 239-257.

Billah, M. K., Afreh-Nuamah, K., Obeng-Ofori, D., \& Nyarko, G. (2015). Review of the pest status, economic impact and management of fruit-infesting flies (Diptera: Tephritidae) in Africa. African Journal of Agricultural Research, 10(12), 1488-1498. https://doi.org/10.5897/AJAR2014.9278

Cordeiro, E., Nunes, Y. L., Mattos, A. L., Rosa, M. F., de sá M Sousa Filho, M., \& Ito, E. N. (2014). Polymer Biocomposites and Nanobiocomposites Obtained from Mango Seeds. Macromolecular Symposia, 344(1), 39-54. https://doi.org/10.1002/masy.201300217

De Sousa Oliveira, L., Costa, M. C. G., de Sousa, H. A., Blum, J., da Silva, G. H. A., de Abreu, M. G. P., \& de Sousa Maia, D. (2018). Characterization of Organic Wastes and Effects of Their Application on the Soil. Journal of Agricultural Science, 10(6), 291. https://doi.org/10.5539/jas.v10n6p291

Duran-Trujillo, Y., Otero-Colina, G., Ortega-Arenas, L. D., Padilla, V. J. A., Mora-Aguilera, J. A., Damián-Nava, A., \& García-Escamilla, P. (2017). Evaluación de insecticidas para control de trips y ácaros plagas del mango (Mangifera indica L.) en Tierra Caliente, Guerrero, México. Tropical and Subtropical Agroecosystems, 20(3), 381-394.

FAOSTAT. (2016). Agriculture Organization of the United Nations Statistics Division, Economic and Social Development Department, Rome, Italy.

Giraldo, L. M., Correa, H. M., Gutiérrez, J. B., \& Castano, C. C. (2007). Aprovechamiento del residuo agroindustrial del mango común (Mangifera indica L.) en la obtención de azúcares fermentables. Ingeniería y Ciencia-ing., 3(6), 41-62.

Infante, F., Quilantán, J., Rocha, F., Esquinca, H., Castillo, G., Ibarra, N., \& Palacio, V. (2011). Mango Ataulfo: Orgullo Chiapaneco. Biodiversitas, 96, 1-5.

Jahurul, M. H. A., Zaidul, I. S. M., Ghafoor, K., Al-Juhaimi, F. Y., Nyam, K. L., Norulaini, N. A. N., \& Omar, A. M. (2015). Mango (Mangifera indica L.) by-products and their valuable components: A review. Food chemistry, 183, 173-180. https://doi.org/10.1016/j.foodchem.2015.03.046

Juárez-López, A. L., Sampedro-Rosas, M. L., \& Rosas-Acevedo, J. L. (2015). Disposición final de residuos sólidos urbanos en dos municipios de la región de Costa Chica del estado de Guerrero, México. Revista Latinoamericana el Ambiente y las Ciencias, 6(12), 333-337.

Lorenzo-Santiago, M. A., Rendón-Villalobos, J. R., García-Hernández, E., Juárez-López, A. L., \& Rosas-Acevedo, J. L. (2017). Caracterización de almidón obtenido de mesocarpio de mango (Mangifera indica L.). Journal CIM, 5(2), 1005-1010.

Lorenzo-Santiago, M. A., Rendón-Villalobos, J. R., García-Hernández, E., Juárez-López, A. L., \& Trujillo-Hernández, C. A. (2016). Obtención y caracterización estructural de celulosa extraída de endocarpio fibroso de mango (Mangifera indica L.). Journal CIM, 4(1), 669-674. 
Martínez, C. M., Paredes, A., Rodríguez, M. E., Álvarez, M. J. M., Camacho, D. R. B., García, D., \& Escalona, C. E. O. (2010). Evaluación de dos métodos de extracción de almidón a partir de cotiledones de mango. Bioagro, 22(1), 67-74.

Mukherjee, S. K., \& Litz, R. E. (2009). Introduction: Botany and importance. The mango: Botany, production and uses (2nd ed., Chapter 1). UK: CABI.

Munro-Olmos, D., Ramos-Serrano, J., Prieto-Martínez, J. J., Rebolledo-Domínguez, O., Lezama-Gutiérrez, R., Sandoval-Salazar, J. R., \& Salazar-Fuentes, V. H. (2008). Guía para la prevención y control de plagas y enfermedades del cultivo del mango, en el estado de Colima, México (p. 78). Comité Estatal de Sanidad Vegetal.

NOM-083-SEMARNAT-2003, Norma Oficial Mexicana. (2004). Especificaciones de protección ambiental para la selección del sitio, diseño, construcción, operación, moni toreo, clausura y obras complementarias de un sitio de disposición final de residuos sólidos urbanos y de manejo especial. Diario oficial de la federación, publicado el 20 de octubre de 2004. Retrieved from http://www.dof.gob.mx/nota_detalle.php?codigo= $658648 \&$ fecha $=20 / 10 / 2004$.

Noriega-Cantú, D., Pereyda Hernández, Garrido Ramírez, E. R., J., Jiménez Guillén, R., \& Cruzaley-Sarabia, R. (2014). Manejo integrado de la antracnosis y caída de frutos de mango ataulfo en las costas de Guerrero. SAGARPA-INIFAP-CIRPAS, Campo experimental Iguala, Iguala de la Independencia, Guerrero, México. Retrieved from http://biblioteca.inifap.gob.mx:8080/jspui/bitstream/mango/123456789/4287/01020814510 0069230_CIRCIR.pdf? sequence $=1$

O'Brine T., \& Thompson, R. C. (2010). Degradation of plastic carrier bags in the marine environment. Marine Pollution Bulletin, 60(1), 2279-2283. https://doi.org/10.1016/j.marpolbul.2010.08.005

Quispe Limaylla, A. (2015). El valor potencial de los residuos sólidos orgánicos, rurales y urbanos para la sostenibilidad de la agricultura. Revista Mexicana de Ciencias Agrícolas, 6(1), 83-95. https://doi.org/ 10.29312/remexca.v6i1.741

RDS (Red para el Desarrollo Sostenible de México, A.C.). (2003). Elaboración del programa de necesidades de Investigación y transferencia de tecnología en el estado de Guerrero. Informe Etapas II, III, IV y V Estudio Cadena agroalimentaria del mango/2. Cofupro, México.

Rivas Tovar, L. A., Peña Cruz, M. D. P., \& Gómez Tagle, M. G. (2005). Competitividad de los productores de mango en la Costa Grande en el Municipio Técpan de Galeana, Estado de Guerrero de México. Investigación Administrativa, 96, 21-37.

Rodríguez, C. M., Guerrero, B. M., Sandoval, R., Martínez, M., \& Reflate, R. (2002). Guía Técnica del Cultivo de Mango. Centro Nacional de Tecnología Agropecuaria y Forestal (CENTA).

Rubio-Anaya, M., \& Guerrero-Beltrán, J. A. (2012). Polímeros utilizados para la elaboración de películas biodegradables. Temas Selectos de Ingeniería de Alimentos, 6, 173-81.

SAGARPA (Secretaría de Agricultura, Ganadería, Desarrollo Rural Pesca y Alimentación). (2011). Informe de Evaluación de Avances logrados entre 2006 y 2010 "Contra La Mosca De La Fruta" En La Cadena de valor del Mango. Retrieved from http://www.sagarpa.gob.mx/Delegaciones/guerreroguerrero/Documents.pdf.

SAGARPA-SIAP (Secretaría de Agricultura, Ganadería, Desarrollo Rural Pesca y Alimentación). (2017). Atlas agroalimentario. Retrieved from http://siap.gob.mx/gobmx_publicaciones_siap/pag/2017/AtlasAgroaliment ario2017

SAGARPA-SIAP (Secretaría de Agricultura, Ganadería, Desarrollo Rural, Pesca y Alimentación). (2018). Centro de Información Agropecuaria y Pesquera Estadísticas de la producción agrícola en México. Retrieved from http://infosiap.siap.gob.mx:8080/agricola_siap_gobmx /Avance Nacional Cultivo.do

Santos-Villalobos, S. D. L., Folter, S. D., Délano-Frier, J. P., Gómez-Lim, M. Á., Guzmán-Ortiz, D. A., \& Peña-Cabriales, J. J. (2011). Puntos críticos en el manejo integral de mango: Floración, antracnosis y residuos industriales. Revista Mexicana de Ciencias Agricolas, 2(2), 221-234.

SENASICA (Servicio Nacional de Sanidad Inocuidad y Calidad Agroalimentaria). (2010). Retrieved from $\mathrm{http} / / /$ mail2.senasica.gob.mx/default.asp?id=1010.

Serna-Cock, L., \& Torres-León, C. (2015). Agro industrial potential of peels of mango (Mangifera indica) Keitt and Tommy Atkins. Acta Agronómica, 64(2), 110-115. https://doi.org/10.15446/acag.v64n2.43579 
Sumaya-Martínez, M. T., Sánchez Herrera, L. M., Torres García, G., \& García Paredes, D. (2012). Red de valor del mango y sus desechos con base en las propiedades nutricionales y funcionales. Revista Mexicana de Agronegocios, 16(30), 826-833.

Tharanathan, R. N., Yashoda, H. M., \& Prabha, T. N. (2006). Mango (Mangifera indica L.), "The king of fruits"-An overview. Food Reviews International, 22(2), 95-123. https://doi.org/10.1080/87559120600 574493

Webb, H. K., Arnott, J., Crawford, R. J., \& Ivanova, E. P. (2012). Plastic degradation and its environmental implications with special reference to poly (ethylene terephthalate). Polymers, 5(1), 1-18. https://doi.org/ 10.3390/polym5010001

Wei, J., Liu, G., Liu, D., \& Chen, Y. (2017). Influence of irrigation during the growth stage on yield and quality in mango (Mangifera indica L.). PLoS One, 12(4). https://doi.org/10.1371/journal.pone.0174498

\section{Copyrights}

Copyright for this article is retained by the author(s), with first publication rights granted to the journal.

This is an open-access article distributed under the terms and conditions of the Creative Commons Attribution license (http://creativecommons.org/licenses/by/4.0/). 